\title{
Top-Down Regulation of Hemlock Woolly Adelgid (Adelges Tsugae) in Its Native Range in the Pacific Northwest of North America
}

Ryan S Crandall ( $\sim$ rscrandall91@gmail.com )

University of Massachusetts Amherst https://orcid.org/0000-0003-2840-5088

Jeffrey A. Lombardo

Hood College

Joseph S. Elkinton

University of Massachusetts Amherst

\section{Research Article}

Keywords: Predator exclusion, insect predators, artificial infestation, Tsuga canadensis, Tsuga heterophylla

Posted Date: February 18th, 2022

DOI: https://doi.org/10.21203/rs.3.rs-1352184/v1

License: (c) (1) This work is licensed under a Creative Commons Attribution 4.0 International License. Read Full License 
Top-down regulation of hemlock woolly adelgid (Adelges tsugae) in its native range in the Pacific Northwest of North America

\author{
Ryan S. Crandall ${ }^{1,3,4}$, Jeffrey A. Lombardo ${ }^{1,2,4}$, and Joseph S. Elkinton ${ }^{1,4}$ \\ ${ }^{1}$ Department of Environmental Conservation, University of Massachusetts, Amherst, MA 01003, \\ USA \\ ${ }^{2}$ Current address: Department of Biology, Hood College, Frederick, MD 21701, USA \\ ${ }^{3}$ Corresponding author, e-mail: rcrandall@umass.edu
}

${ }^{4}$ Author contributions: JE obtained funding and provided overall management of the project. JE and JL formulated the study design. JL and RC collected the data. RC conducted statistical analyses and wrote the manuscript. JE and JL edited drafts of the manuscript. 
1 Abstract

The density of insect herbivores is regulated by top-down factors (e.g., natural enemies),

3 bottom-up effects (e.g., plant defenses against herbivory), or a combination of both. As such,

4 understanding the relative importance of these factors can have important implications for the

5 establishment of effective management options for invasive species. Here, we compared the

6 relative importance of top-down and bottom-up factors on the abundance of hemlock woolly

7 adelgid (HWA), Adelges tsugae. HWA is invasive in eastern North America, but its native range

8 includes the Pacific Northwest of North America where it has co-evolved with western hemlock,

$9 \quad$ Tsuga heterophylla. Eastern hemlock, Tsuga canadensis, can also be found planted in city and

10 park settings in the Pacific Northwest and the presence of both host species allowed us to directly

11 compare the importance of predators (top-down) and host plant resistance (bottom-up) on HWA

12 abundance by placing mesh exclusion bags on branches of both species and monitoring HWA

13 abundance over two years. We found no evidence for bottom-up control of HWA on western

14 hemlock (a native host). HWA established more readily on that species than on eastern hemlock

15 on which it is a major pest in eastern North America. We found strong evidence for top-down

16 control in that both summer and winter-active predators significantly reduced HWA densities on

17 the branches of both tree species where predators were allowed access. These findings support

18 the validity of the biological control program for HWA, the goal of which is to reduce outbreak

19 populations of HWA in eastern North America.

\section{Keywords}

22 Predator exclusion, insect predators, artificial infestation, Tsuga canadensis, Tsuga heterophylla 


\section{Introduction}

The densities of many herbivores are regulated through a combination of factors that include mortality caused by natural enemies (top-down effects), and reductions in fitness mediated by plant defenses against their feeding (Hunter and Price 1992; Power 1992). Recent studies of herbivorous insects have shown that top-down control usually has a larger effect than bottom-up control, although there is considerable variation related to factors such as diet breadth (e.g., specialists versus generalists) and feeding guild (Vidal and Murphy 2018). The view that densities of terrestrial herbivores are mainly regulated by top-down factors was argued by Hairston et al. (1960) and supported by others including Lawton and Strong (1981) and Strong et al. (1984). Murdoch (1966) challenged this idea and Denno et al. (1995) provided many counterexamples. Fretwell and Barach (1977) and Oksanen et al. (1981) argued that number of trophic levels in a community may determine the relative importance of top-down versus bottom-up regulation of herbivore density. The densities of natural enemies of herbivores are often held at low densities by their own natural enemies in the trophic level above. Clear examples of herbivores attacking forest trees that are regulated by bottom-up forces include bark beetles (Scolitinae) whose densities are typically determined by the availability of host trees whose defenses are weakened by environmental factors (Biedermann et al. 2019). As a result, ecologists have long sought to understand the relative importance of these top-down versus bottom-up effects: identifying and quantifying the relative importance of these factors is critical to understanding and implementing effective management strategies for invasive pest species (Hovick and Carson 2015).

Hemlock woolly adelgid (HWA), Adelges tsugae Annand (Hemiptera: Adelgidae), is a sap-feeding insect on hemlock (Tsuga) species native to eastern Asia and the Pacific Northwest 
46 region of North America (hereafter Pacific Northwest), where multiple distinct lineages of HWA

47 have coevolved with different species of hemlock trees found across its range (Havill et al.

48 2016). In the Pacific Northwest, HWA is associated with western hemlock, Tsuga heterophylla

49 [Rafinesque] Sargent (Pinaceae: Pinales), a species commonly found across this region (McClure

50 1992). However, while western hemlock is a dominant understory tree in this region, HWA

51 typically occurs at low densities (McClure 1992). In contrast, HWA in eastern North America is

52 a non-native pest that was introduced from Japan (Havill et al. 2016). This Japanese lineage of

53 HWA can reach high densities in its introduced range where it is responsible for the widespread

54 mortality of eastern hemlock, T. canadensis [L.] Carriere, and Carolina hemlock, T. caroliniana

55 Engelmann, across much of eastern North America (Havill et al. 2014). Various studies suggest

56 that HWA populations in eastern North America are primarily regulated by bottom-up factors in

57 the form of competition for space on hemlock twigs and HWA-induced reduction of new

58 hemlock shoots that the insect depends on for the next generation of HWA populations (McClure

59 1991; Elkinton et al. 2011; Sussky and Elkinton 2014). There are no known parasitoids of HWA

60 (Cheah et al. 2004) and natural enemies native to eastern North America play an insignificant

61 role in regulating HWA densities (McClure 1987; Montgomery and Lyon 1996; Wallace and

62 Hain 2000).

Given the economic and ecological importance of hemlock trees, the USDA Forest

64 Service has devoted significant funding to the importation, mass rearing, and release in eastern

65 North America of various insect predators of the Japanese HWA lineage. Some of these

66 predators, such as Laricobius nigrinus Fender (Coleoptera: Derodontidae) from the Pacific

67 Northwest, have established self-sustaining populations and are spreading from many release

68 locations (Mausel et al. 2010; Foley et al. 2019; Jubb et al. 2021). There has been very limited 
69 success with these introductions in terms of reducing HWA populations despite high predation

70 rates (see Crandall et al. 2020; Jubb et al. 2020), suggesting that bottom-up forces might also be

71 important in determining HWA abundance in its native and introduced ranges.

72 We studied the relative importance of top-down and bottom-up forces on HWA densities

73 in its native range in the Pacific Northwest by inoculating branches of both eastern and western

74 hemlock trees and excluding predators from half of the inoculated branches. By comparing plant

75 host and predation simultaneously, we directly examined (1) the relative importance of summer-

76 active and winter-active native predators, (2) whether HWA colonization and abundances

77 differed by tree species, and (3) the relative importance of top-down and bottom-up forces on

78 HWA feeding on native and non-native hosts in its native range.

\section{Methods}

80 HWA life cycle and feeding

HWA feeds by settling at the base of a hemlock needle and inserting their long thin

82 mouthparts, called stylets, into the twig to feed on ray parenchyma cells (Young et al. 1995).

83 HWA are parthenogenic and produce two generations per year, the overwintering sistens

84 generation and the spring progrediens generation (McClure 1987). The sistens generation hatch

85 in the summer, settle on freshly produced new growth, aestivate until early fall, feed through the

86 winter, and oviposit from late winter through early spring (McClure 1987; Sussky and Elkinton

87 2015). In spring, the progrediens eggs hatch and the progrediens first instar nymphs, commonly

88 referred to as "crawlers", settle and feed on the same growth as the parent sistentes (plural for

89 sistens), until early to mid-summer when they lay sistens eggs (McClure 1991). The progrediens

90 generation can either become adult progredientes or winged sexuparae (McClure 1991; Sussky 
91 and Elkinton 2014), which, in the native range, seek out tigertail spruce, Picea torano (K. Kock)

92 Koehne, to carry out a sexual generation (Havill et al. 2006). Sexuparae produced in eastern

93 North America fail to reproduce because no suitable native spruce host exists; sexuparae have

94 not been previously observed in the Pacific Norwest (Zilahi-Balogh et al. 2003).

\section{Collection of HWA inoculum and deployment on experimental branches}

96

97

Two year-long rounds of inoculations and observations of hemlock woolly adelgidinfested hemlock branches were carried out in the Washington Park Arboretum in Seattle, Washington, USA in 2015 and 2017. In March of 2015 natural infestations of HWA were found in Green Lake Park, Seattle, WA (47.671072, -122.344422). In March of 2017, natural infestations of HWA were found in the Olympic Peninsula in the town of Sequim, WA, USA (48.078056, -123.101389). Hemlock woolly adelgid-infested branchlets were chosen that had no or few signs of predation and 20 to 200 ovisacs. Branchlets were clipped, the number of ovisacs counted, and branchlets randomly grouped into bundles of 1, 3, or 5 and placed in bricks of water-soaked floral foam (Smithers-Oasis Kent Co. OH, USA) to prevent desiccation. Branchlets were stored in bins that were kept indoors at room temperature for approximately four days until deployment.

$$
\text { We deployed inoculum onto experimental branches on 23-March-2015 and 27-March- }
$$
2017. Inoculum branchlets deployed at Washington Park Arboretum in bundles of 1, 3, 10, and 20 on experimental branches to create varying densities of ovisacs with a range of 100 to 1,400 ovisacs per bundle. Twenty hemlock trees (10 eastern and 10 western) were identified and two pairs of uninfested branches per tree were labeled to be used as experimental branches. Branches within each pair were given equivalent densities of ovisacs. Inoculum densities were randomly assigned to branch pairs. The pairs were then given bundles of 1, 3, 10, or 20 branchlets, 
114 corresponding to their assigned inoculum density, that were then fixed onto the branches with

115 plastic cable ties. Predator exclusion bags (1-m-long by 0.5-m-wide Equinox ${ }^{\circledR}$ No-See-Um

116 mosquito netting, $\sim 569$ holes per square centimeter) were then placed over all branches and tied

117 on using strips of self-stick vinyl foam insulation $(3.2 \mathrm{~cm} \mathrm{x} 48 \mathrm{~mm})$ between the branch and the

118 cable tie so that ties did not cut off nutrient and water flow. Sample branches were monitored

119 over the next few weeks to confirm that nymphs had settled by examining inoculum ovisacs with

120 a hand lens for the presence of eggs, as well as checking the sample branches visually for settled

121 nymphs. In April of 2015 and 2017, the mesh bags were removed from one branch in each pair

122 and the inoculation bundles were removed from all branches. The mesh bag remained on the

123 second branch in each pair to restrict predators from reaching the HWA on that branch. In June

124 of 2015, densities of HWA were very low; >0.1 adelgid per centimeter. Branches with some

125 HWA were kept in the study and natural infestations found in the arboretum were incorporated

126 into the study by choosing branch pairs with similar densities of HWA and bagging one of the

127 branches. Before bagging, branches were shaken about 20 times to remove any predators that

128 may have been on the branch.

129 Density data collection

130 For round one of this experiment (i.e., 2015-2016), densities of HWA were estimated by

131 removing 30-cm branchlets and counting HWA life stages. Length of branchlet growth and

132 counts of hemlock woolly adelgid on branchlets were observed with a dissecting microscope. In

133 June of 2015, the density of progrediens was estimated on both inoculated and naturally infested

134 branches. Adelgid densities on naturally infested branches were sampled in November of 2015

135 (maturing sistens) and March of 2016 (adult sistens). During these sampling periods, HWA

136 populations on inoculated branches were still establishing, and therefore had very low sistens 
137 densities and were not sampled until November 2016. In June 2016, progrediens densities were

138 counted on the naturally infested branches. In November of 2016, the maturing sistens

139 generation was quantified on both the inoculated branches and naturally infested branches. The

140 inoculated branches were also sampled for the past progrediens generation as their ovisacs were

141 still present on the tree and were clearly distinguishable from the smaller fresh ovisacs of the

142 maturing sistens generation.

Round two of this experiment was initiated in March 2017, using the same inoculation

144 method as round 1. From mid-June through mid-July of 2017, sample branches were checked

145 weekly to monitor the progress of the progrediens generation to measure settlement on sample

146 branches. Of the 20 paired branches inoculated for each tree species, 17 pairs were successfully

147 inoculated for western hemlock and 13 pairs were successfully inoculated for eastern hemlock.

148 On each sample branch, 30-cm branchlets were chosen and marked with twist ties for

149 later, non-destructive sampling. In the field, the numbers of progrediens nymphs and adults per

150 centimeter on the marked branchlets were counted using a hand lens and headlight. The 30-cm

151 long branchlets were again sampled in November 2017 and in March 2018 to record the number

152 of maturing and adult sistens, respectively. In July 2018, progrediens densities were recorded.

153 Surveying natural HWA abundance

154 HWA densities were quantified at 36 sites in three regions in western Washington state

155 (12 sites per region) to compare HWA abundance in each region. Hemlock trees were checked

156 for HWA presence in three locations: Seattle, Washington (urban), Route 90 and Route 2 (rural),

157 and the Olympic Peninsula (rural). Sites were either forests or wooded areas in parks and were at

158 least one kilometer from other sites. In mountainous regions, we limited sites to below 1,500 ft 
159 elevation to reduce the effect of elevation as a confounding factor. Where possible, 20 trees per 160 site (10 trees minimum where hemlock was less abundant) were sampled which involved

161 checking the top and bottom of one-meter-long branch and rating the HWA infestation or lack

162 thereof. We used a 0-3 scale of HWA infestation $(0=$ none; $1=1-10$ ovisacs $/ \mathrm{m}$ branch; $2=11$ -

163100 ovisacs $/ \mathrm{m}$ branch; $3=101-1000$ ovisacs $/ \mathrm{m}$ branch), adapted from the methods used in

164 Preisser et al. (2008). We also added in sites from New England to compare the densities from

165 Washington to those in the invaded range of HWA. Sites were mainly from Massachusetts, but

166 included one site from Vermont, one site from New Hampshire, and three sites from Maine. The

167 same techniques were used to collect HWA abundance as described for Washington.

168 Data analysis

To look for differences in establishment of HWA by tree species, we subset our data to

170 look only at bag data. By looking at the bag data separately, we remove any effect of predation

171 on HWA establishment and isolate the effect of tree species on HWA establishment success.

172 Data for this analysis were coded as a " 1 " if the branch had HWA and a " 0 " if the branch did not 173 have HWA and were analyzed using a binomial 'glm' model in R version 4.1.2. Only data from

174 Round 2 were used as this data had better establishment.

Densities of hemlock woolly adelgid were compared between treatments by branch pairs

176 for each generational life stage on each tree species using two generalized linear mixed model

177 (GLMM). The 'glmmTMB' function (Package $=g l m m T M B$, Version 1.1.2.3) was used for zero-

178 inflated data by specifying in the model a zero-inflation factor and using a zero-inflated Gamma

179 family of distributions. Each model had a random effect for branch pair (Bates et al. 2015). The

180 "Maturing Sistens 2016" failed to converge using the 'glmmTMB' function due to low sample

181 size and the data being heavily zero-inflated. Instead, we ran that data with the 'glmer' function, 
182 using the Gamma distribution, and added a small constant (0.0001) to the response variable

183 (HWA density) to permit analysis even when HWA were absent (Zar 2010). In addition to

184 testing our data with GLMM models, we also analyzed HWA densities with the Wilcoxon signed

185 rank test since our data was not normally distributed. Adding a non-parametric test compliments

186 and supports the results from our parametric GLMM tests.

Rates of survival were compared between species and treatments for the progrediens generation in spring 2017 as well as the maturing sistens generation in fall 2017. These were the only two generations for which we had a full sampling of the generation from settlement to adult or maturing stages. To analyze the proportion of HWA surviving by treatment the 'glmer'

191 function was used for each generation on both tree species. In each model, branch pair was a 192 random effect, the response variable was a two-column vector containing the counts of live and 193 dead HWA for each branch sample, and the binomial distribution as used. The binomial models 194 were checked for overdispersion, but no overdispersion was found.

Throughout the 2017-2018 experiment, we used iButtons (Maxim Integrated, San Jose, CA) to record air temperatures at two-hour intervals in both the bagged and unbagged treatments

197 to test for between-treatment differences in air temperature between bagged and unbagged 198 treatments that might potentially account for increased densities inside bagged treatments. We 199 used data recorded from January 2018 to July 2018 because it was the most complete dataset 200 from the two years. Data were summarized to daily average temperatures and analyzed using the 201 'lm' function (Package = "stats", Version = 4.1.2). HWA survey abundance data was analyzed using a non-parametric Kruskal-Wallis test 203 because the data were non-normally distributed. The Kruskal-Wallis test allowed us to test for 204 differences in average abundance between each of the regions that we sampled, acting 
205

206

207

208

209

210

211

212

213

214

215

216

217 Results

218

219

220

221 222 founding progrediens generation (Table 1).

223

224

225 using ggplot2 (Wickham 2009). denotes no significant effect.

\section{HWA densities and survival exclusion treatment}

analogously to a one-way ANOVA test. We also looked for differences in the percentage of branches with HWA by region using a 'glm' model with a quasibinomial distribution.

All analyses were performed in R 4.1.2 (R Core Team 2021). All graphs were prepared

\section{Literature review of HWA fitness on $T$. canadensis and $T$. heterophylla}

The Web of Science database and Google Scholar were queried to find publications that compared HWA density, survival, and/or fecundity on both T. canadensis and T. heterophylla.

Search terms included combinations of the words "Adelges tsugae", "Tsuga canadensis", "Tsuga heterophylla", "host resistance”, "bottom-up" “top-down”, “predator exclusion experiment”. The main findings of each of the studies were recorded in a table with either a ">", "<", or " =" sign to show the direction of the results. Symbols " $>$ " and "<" denote significant effects while "="

\section{Effect of tree species on HWA establishment and survival}

HWA settled more readily on western hemlock than eastern hemlock (Table 1). Splitting the data by HWA generation, we found that initial establishment rates were lower on eastern hemlock, and that HWA populations declined on eastern hemlock after the completion of the

In the first experiment (Round one, 2015-2016 sampling period) (Figs. 1A-B), HWA densities in both bagged and unbagged treatments were generally low $(<1$ HWA per cm). HWA 
226 densities on bagged and unbagged western hemlock branches were only significantly different

227 for the progrediens adults 2016 (Table S1D); all other sample periods were not significant (Table

228 S1A-C and S1E). On eastern hemlock, densities of progrediens adults 2015 and progrediens

229 adults 2016 were not significantly different between the bagged and unbagged treatments (Table

230 S2A and S2D) but there was a significant difference for the maturing sistens in November 2016

231 (S2E; Fig. 1A). Densities of HWA were too low for collection on eastern hemlock for the

232 maturing sistens in 2015 and for the adult sistens in 2016.

233 In the second experiment (Round two, 2017-2018 sampling period) (Figs. 1C-D), there

234 was no significant difference between treatments on either hemlock species for the density of

235 established progrediens nymphs following inoculation at the start of the experiment, as we had

236 intended. On western hemlock there were statistically significant differences in density between

237 bagged and unbagged treatments at all the subsequent sampling points ( 5 life stages, 4

238 consecutive generations) (Table S1G-K). On eastern hemlock (Table S2F-K), only the adult

239 sistens in March 2018 (Table S2I) had a significant difference between treatments. The overall

240 lower establishment (Table 1) of HWA on eastern hemlock compared to western hemlock

241 reduced the number of replicates we had on that species and thus compromised our statistical

242 power.

243 The results of the Wilcoxon signed rank test were mostly in agreement with those from

244 our GLMM models (Table S1 and S2). Results did differ for western hemlock sistens adults

2452016 (Table S1C) with the Wilcoxon signed rank test finding a significant difference where our

246 GLMM model did not. For eastern hemlock, the Wilcoxon test did not find the maturing sistens

2472016 to be significantly different (Table S2E), and it did find the maturing sistens 2017 to have a 
248 significant treatment effect (Table S2H). For all other generations, the Wilcoxon signed rank test 249 agreed with the results from our GLMM models.

250 The difference between treatments for the survival data was highly significant for both 251 tree species in the progrediens generation in 2017, with higher survival in the bagged treatment 252 (eastern hemlock: $Z=-4.17, P=<0.001$; western hemlock: $Z=-23.97, P=<0.001$ ) (Table 2A).

253 For the maturing sistens in November 2017, we found that there was significantly higher survival 254 in bagged treatments on eastern hemlock, however, there were no significant differences in 255 survival on western hemlock (eastern hemlock: $Z=-2.362, P=0.0182$; western hemlock: $Z=$ $2561.158, P=0.2467$ ) (Table 2B). Due to destructive sampling and difficulty in telling sistens 257 nymphs and progrediens nymphs apart when settled together, we only analyzed this data for the 258 progrediens in 2017 and the maturing sistens in 2017.

259 The daily mean air temperature data from both bagged and unbagged treatments were 260 indistinguishable $(\mathrm{t}=-0.062, \mathrm{df}=398, P=0.951)$.

\section{Predator collections}

Predator samples, collected opportunistically from progrediens ovisacs while estimating 263 density, were identified using cytochrome oxidase subunit I (CO1) DNA barcoding. Fly larvae 264 found foraging on progrediens ovisacs included three species of chamaemyiid flies (Leucotaraxis 265 piniperda Malloch, Le. argenticollis Zetterstedt and one Neoleucopis sp.), two species of 266 cecidomyiid flies (not identified to genus), and syrphid flies (not identified to genus). We also 267 frequently observed predatory true bugs (Hemiptera) including Lygaeidae (Kieidocerys resedae 268 (Panzer)), Anthocoridae, Reduviidae, and green lacewing nymphs (Chrysopidae) (all three not 
269 identified to genus) and much less frequently (3-4 individuals over the course of the experiment)

270 the coccinellid Harmonia axyridis.

\section{Survey for natural HWA abundance}

HWA abundance and percentage of branches with HWA were higher in New England

273 than Washington (Fig. 2). Within Washington, HWA abundance (Fig 2A) and percentage of

274 branches with HWA (Fig. 2B) were significantly higher in Seattle than the Cascades (Route 90

275 and Route 2) and the Olympic Peninsula; there was no difference between the Cascades and the

276 Olympic Peninsula.

\section{Findings from HWA literature review}

Our HWA literature review (Table 3) found mixed conclusions regarding HWA fitness

279 when feeding on T. canadensis and T. heterophylla. Results also suggest a possible difference in

280 HWA fitness on the two tree species depending on the HWA lineage used, i.e., Japanese lineage:

281 Table 3A-E, and North American lineage: Table 3F)

282 Discussion

We had no difficulty inoculating western hemlock branches with HWA and achieving

284 within-bag densities comparable to those in outbreak populations of HWA on eastern hemlock in 285 eastern North America (Fig. 1) (McClure 1991; Jubb et al. 2020). We thus have no evidence that 286 the low HWA densities found on western hemlock in the Pacific Northwest are due to bottom-up 287 interactions between HWA and its hemlock host. Our findings instead suggest that the western 288 lineage of HWA is better suited to settling on western hemlock than eastern hemlock (Table 1). 
Our predator exclusion results provided strong support for the hypothesis that predator-

290 related mortality maintains the low HWA densities found on western hemlock throughout the

291 Pacific Northwest (Table 2A). These findings support the validity of the biological control

292 program for HWA, which has devoted significant resources to the importation and release of

293 predator species from the Pacific Northwest, to reduce outbreak populations of HWA in eastern

294 North America. Until now, there have been no studies investigating whether these insect

295 predators suppress HWA to low densities in the Pacific Northwest.

296 In our data, survival was significantly lower on unbagged branches during the

297 progrediens generation in 2017 (Table 2A) implying summer-active predator feeding on HWA as

298 the direct cause. There was also significantly lower survival in the maturing sistens nymph stage

299 in November 2017 on eastern hemlock (Table 2B). Generalist summer-active predators, as well

300 as Leucotaraxis spp., are active during the aestivating sistens stage up until about October

301 (Kohler et al. 2016), when La. nigrinus adults are active beginning in September (Zilahi-Balogh

302 et al. 2003). This could explain the lower HWA survival outside of bags during the maturing

303 sistens nymph stage (data taken in November). These data support the recent decision of the

304 USDA Forest Service to refocus the HWA biological control effort on introducing two species of

305 silver flies, Le. argenticollis and Le. piniperda, that feed on both the sistens and progrediens

306 generation of HWA in the Pacific Northwest (Kohler et al. 2016). Previous efforts focused on

307 introducing La. nigrinus that feeds on the overwintering sistens generation on HWA. That

308 species has been widely established in the eastern U.S. (Mausel et al. 2010; Foley et al. 2019;

309 Jubb et al. 2021) and has caused significant mortality to HWA ovisacs (Jubb et al. 2020), but the

310 mortality is insufficient to regulate densities of HWA (Crandall et al. 2020). Our results imply 
311 that a combination of summer-active and winter-active predators will be required to suppress

312 densities of HWA in eastern North America.

313 One alternative explanation for higher HWA densities in bagged versus unbagged

314 treatments is that bags may inhibit crawler dispersal and thus artificially inflate the bagged

315 treatment densities. This effect would not influence the data we took on HWA survival (Table

$3162 \mathrm{~A}$ ), which was measured as a proportion of the HWA nymphs settled on hemlock twigs post-

317 dispersal. Furthermore, it would not have affected the difference between treatments in HWA

318 density in the 2017 progrediens generation, because bags were placed on both bagged and

319 unbagged treatments until progrediens crawlers had finished dispersing and settling on new

320 branches. However, it might have affected the density of the subsequent sistens generation. In a

321 separate study conducted in Deerfield, MA in 2020 (unpublished data) we tested for a mesh bag

322 effect on sistens crawler dispersal. We compared the ratio of observed to expected sistens

323 nymphs between bag treatments and found that there was significant but small effect of bag $(\mathrm{T}=$

$324-2.78, \mathrm{df}=28, P=0.0096)$ with a ratio of $3.14( \pm 0.25)$ for bag vs $3.02( \pm 0.35)$ for no bag

325 (Crandall unpublished data). These small but significant differences were expected because the

326 holes in the predator exclusion bags are larger than the size of a first instar HWA crawler and we

327 have witnessed them moving through the bag. We also addressed the possibility of a temperature

328 related bag effect by measuring temperature inside and outside of predator exclusion bags and

329 found no between-treatment differences in air temperature (Fig. A1).

The large differences in HWA abundance and percentage of HWA-infested branches

331 between New England and Washington (Fig. 2) confirm what we and others (McClure 1992;

332 Mausel 2005) have long observed: HWA is rarely found on western hemlock in western forests.

333 Higher HWA densities at the urban site (Seattle, WA) are likely explained by the lower densities 
334 of HWA predators in such non-forest settings. When we and previous investigators (e.g., Weed

335 et al. 2016) searched for high-density HWA populations to obtain inoculum for these

336 experiments, we nearly always found them in urban areas (Seattle) or on isolated trees, such as in

337 parking lots, along the side of the road, and elsewhere. When we returned to those same trees in

338 the following years, we nearly always found low densities of HWA. It may be that HWA

339 populations on trees at such sites can occasionally 'escape' predator control, reaching high

340 densities until predators aggregate to their location and decrease their numbers.

Previous artificial hemlock inoculation studies have reported conflicting results regarding

342 the relative performance (i.e., ability to settle, survive and reproduce) of HWA in the eastern

343 U.S. on eastern hemlock versus western hemlock (Table 3). It is worth noting that the studies

344 from Table 3A-E used the Japanese HWA lineage collected in the eastern U.S.; this strain has no

345 evolutionary history with T. heterophylla (Havill et al. 2016). In contrast, the western HWA

346 lineage used by Mausel (2005) (Table 3F) has a long evolutionary history with T. heterophylla.

347 Chinese hemlock, Tsuga chinensis (Franch.) E. Pritz, is widely regarded as being completely

348 resistant to HWA (McClure 1992; Bentz et al. 2002; Del Tredici and Kitajima 2004; Hoover et

349 al. 2009; Weston and Harper 2009; Joseph et al. 2011; Lappanen et al. 2019) in studies involving

350 infestation with the Japanese HWA lineage in the eastern U.S. However, Havill and Montgomery

351 (2008) described finding T. chinensis in its native range infested with HWA and even having

352 "dense populations", likely the result of coevolution between $T$. chinensis and its associated

353 lineage of HWA possessing the ability to establish. These conflicting results along with ours

354 suggest that resistance of any Tsuga species to HWA likely depends upon whether the lineage of

355 HWA being tested has co-evolved with that species. 
In summary, we have provided strong support for the hypothesis that western HWA is

357 well-evolved to infest western hemlock and we have no evidence for bottom-up controls of

358 HWA by its native host. In contrast, we provide strong support for top-down control of HWA by

359 a suite of summer-active and winter-active predators. These results suggest that a suite of

360 predators feeding on both generations of HWA may be necessary to reduce HWA populations in

361 the eastern U.S and support the validity of the HWA biological control program.

\section{Acknowledgements}

363 We thank members of the Elkinton Lab for helping with gathering materials (G. Boettner), data 364 collection (A. Langevin, A. Roehrig, J. Chandler, B. Griffin), editing (J. Chandler, J. Andersen, 365 H. Broadley). We thank M. Whitmore, E. Sussky, and E. Hazelton for locating sources of HWA 366 inoculum and/or help with experimental set up. Thanks to N. Havill for identifying insect 367 samples with molecular techniques. We thank R. McDonald for introducing us to the Arboretum.

368 We thank the University of Washington's Washington Park Arboretum (D. Zuckerman, R. 369 Garrison, and staff) for allowing us to set up our experiment in the arboretum and use their 370 equipment and facilities. We thank D. Orwig and E. Preisser for helpful edits to the manuscript.

371 Finally, we thank the USDA Forest Service (R. Reardon, N. Schneeberger) for funding this 372 project.

\section{Declarations}

374 Funding: This study was funded by the U.S. Department of Agriculture Forest Service Grant 375 No. 14-CA-11420004-181

376 Conflict of interest: The authors declare that they have no conflicts of interest.

377 Ethics approval: Not applicable. 
378 Consent to participate: Not applicable.

379 Consent for publication: Not applicable.

380 Availability of data and materials: The datasets used and/or analyzed during the current study

381 are available from the corresponding author on reasonable request.

382 Code availability: The R-script used to analyze the dataset used and/or analyzed during the

383 current study are available from the corresponding author on reasonable request.

384 Author contributions: JE obtained funding and provided overall management of the project. JE

385 and JL formulated the study design. JL and RC collected the data. RC conducted statistical

386 analyses and wrote the manuscript. JE and JL edited drafts of the manuscript 


\section{References}

388

Bates D, Maechler M, Bolker B, Walker S (2015) Fitting linear mixed-effects models using lme4. J Stat Softw 67:1-48. https://doi:10.18637/jss.v067.i01.

Bentz SE, Riedel LGH, Pooler MR, Townsend AM (2002) Hybridization and selfcompatibility in controlled pollinations of eastern North American and Asian hemlock (Tsuga) species. J. Arboric 28:200-205.

Biedermann PH, Müller J, Grégoire JC, Gruppe A, Hagge J, Hammerbacher A, Hofstetter RW, Kandasamy D, Kolarik M, Kostovcik M, Krokene P (2019) Bark beetle population dynamics in the Anthropocene: challenges and solutions. Trends Ecol Evol 34:914-924. https://doi.org/10.1016/j.tree.2019.06.002

Cheah C, Montgomery ME, Salom S, Parker BL, Costa S, Skinner M (2004) Biological control of hemlock woolly adelgid. USDA Forest Service Forest Health Enterprise Team, Technology Transfer, Morgantown, WV.

\section{Crandall RS, Jubb CS, Mayfield AE, Thompson B, McAvoy TJ, Salom SM, Elkinton JS} (2020) Rebound of Adelges tsugae spring generation following predation on overwintering generation ovisacs by the introduced predator Laricobius nigrinus in the eastern United States. Biol Control 145:104-264. https://doi.org/10.1016/j.biocontrol.2020.104264

Del Tredici P, Kitajima A (2004) Introduction and cultivation of Chinese hemlock (Tsuga chinensis) and its resistance to hemlock woolly adelgid (Adelges tsugae). J Arboricul 30:282287.

Denno RF, McClure MS, Ott JR (1995) Interspecific interactions in phytophagous insects: 
competition reexamined and resurrected. Annu Rev Entomol 40:297-331.

Elkinton JS, Trotter RT, Paradis AF (2011) Simulation of population dynamics of hemlock woolly adelgid and potential impact of biological control agents. In: Onken B, Reardon R (eds) Implementation and status of biological control of the hemlock woolly adelgid. USDA Forest Service FHTET-2011-04, Morgantown, WV, pp 15-24. Chapter 2

Foley JR, McAvoy TJ, Dorman S, Bekelja K, Kring TJ, Salom SM (2019) Establishment and distribution of Laricobius spp. (Coleoptera: Derodontidae), a predator of hemlock woolly adelgid, within the urban environment in two localities in southwest Virginia. J Integr Pest Manag 10:30. https://doi.org/10.1093/jipm/pmz027.

Fretwell SD, Barach AL (1977) The regulation of plant communities by the food chains exploiting them. Perspect Biol Med 20:169-185. https://doi.org/10.1353/pbm.1977.0087

Hairston NG, Smith FE, Slobodkin LB (1960) Community structure, population control, and competition. Amer Natur 94:421-425. https://doi.org/10.1086/282146

Havill NP, Montgomery ME (2008) The role of arboreta in studying the evolution of host resistance to the hemlock woolly adelgid. Arnoldia 65:2-9.

Havill NP, Montgomery ME, Yu G, Shiyake S, Caccone A (2006) Mitochondrial DNA from hemlock woolly adelgid (Hemiptera: Adelgidae) suggests cryptic speciation and pinpoints the source of the introduction to eastern North America. Mol Ecol 99:195-203. https://doi.org/10.1603/0013-8746(2006)099[0195:MDFHWA]2.0.CO;2

\section{Havill NP, Shiyake S, Lamb Galloway A, Foottit RG, Yu G, Paradis A, Elkinton J,} Montgomery ME, Sano M, Caccone A (2016) Ancient and modern colonization of North 
429 America by hemlock woolly adelgid, Adelges tsugae (Hemiptera: Adelgidae), an invasive insect 430 from East Asia. Mol Ecol 25:2065-2080. https://doi.org/10.1111/mec.13589

431 Havill NP, Vieira LC, Salom SM (2014) Biology and control of hemlock woolly adelgid.

432 USDA Forest Service FHTET-2014-05, Morgantown, WV

433 Hoover BK, Bates RM, Sellmer JC, Hoover GA (2009) Challenging Chinese hemlock (Tsuga 434 chinensis) with hemlock woolly adelgid (Adelges tsugae) ovisacs. Arboricult Urban For 35:1-4.

435 Hovick SM, Carson WP (2015) Tailoring biocontrol to maximize top-down effects: on the 436 importance of underlying site fertility. Ecological Applications, 25: 125-

437 139. https://doi.org/10.1890/13-2050.1

438 Hunter MD, Price PW (1992) Playing chutes and ladders: Heterogeneity and the relative roles 439 of bottom-up and top-down forces in natural communities. Ecol 73:724-732.

Jetton RM, Hain FP, Dvorak WS, Frampton J (2008) Infestation rate of hemlock woolly

441 adelgid (Hemiptera: Adelgidae) among three North American hemlock (Tsuga) species

442 following artificial inoculation. Entomol Sci 43:438-442. https://doi.org/10.18474/0749-8004-

$443 \quad 43.4 .438$

444 Joseph SV, Braman SK, Hanula JL (2011) Effects of fertilization of four hemlock species on 445 Adelges tsugae (Hemiptera: Adelgidae) growth and feeding preference of predators. J Econ 446 Entomol 104: 288-298. https://doi.org/10.1603/EC10163

447 Jubb CS, Heminger AR, Mayfield III AE, Elkinton JS, Wiggins GJ, Grant JF, Lombardo 448 JA, McAvoy TJ, Crandall RS, Salom SM (2020) Impact of the introduced predator, Laricobius 
449 nigrinus, on ovisacs of the overwintering generation of hemlock woolly adelgid in the eastern

450 United States. Biol Control 143:104180. https://doi.org/10.1016/j.biocontrol.2019.104180

451 Jubb CS, McAvoy TJ, Stanley KE, Heminger AR, Salom SM (2021) Establishment of the

452 predator Laricobius nigrinus, introduced as a biological control agent for hemlock woolly

453 adelgid in Virginia, USA. Biocontrol 66:367-379. https://doi.org/10.1007/s10526-020-10072-5

454 Kohler GR, Wallin KF, Ross DW (2016) Seasonal phenology and abundance of Leucopis

455 argenticollis, and Leucopis piniperda (Diptera: Chamaemyiidae), Laricobius nigrinus

456 (Coleoptera: Derodontidae) and Adelges tsugae (Hemiptera: Adelgidae) in the Pacific Northwest

457 USA. Bull Entomol Res 106:546-550. https://doi.org/10.1017/S0007485316000250

458 Lappanen C, Fordyce JA, LeBude AV, Ranney TG, Simberloff D (2019) Variable

459 colonization by the hemlock woolly adelgid suggest infestation is associated with hemlock host

460 species. Biol Invas 21:2891-2906. https://doi.org/10.1007/s10530-019-02020-X

461 Lawton JH, Strong DR (1981) Community patterns and competition in folivorous insects. Am

462 Nat 118:317-38. https://doi.org/10.1086/283826

463 Mausel DL (2005) Observations on fecundity and natural enemies of hemlock woolly adelgid,

464 Adelges tsugae Annand (Hemiptera: Adelgidae) in Seattle, Washington. Pan-Pac Entomol

$465 \quad 81: 97-98$.

466 Mausel DL, Salom SM, Kok LT, Davis GA (2010) Establishment of the hemlock woolly

467 adelgid predator, Laricobius nigrinus (Coleoptera: Derodontidae), in the eastern United States.

468 Environ Entomol 39:440-448. https://doi.org/10.1603/EN09088 
469 McClure MS (1987) Biology and control of hemlock wooly adelgid, Bulletin 851:1-9 The

470 Connecticut Agricultural Experiment Station, New Haven, CT.

471 McClure MS (1991) Density-dependent feedback and population cycles in Adelges tsugae

472 (Homoptera: Adelgidae) on Tsuga canadensis. Environ Entomol 20:258-264.

473 https://doi.org/10.1093/ee/20.1.258

474 McClure MS (1992) Hemlock woolly adelgid. Am Nurseryman 15:82-89.

475 Montgomery ME, Lyon SM (1996) Natural enemies of adelgids in North America: their

476 prospect for biological control of Adelges tsugae (Homoptera: Adelgidae). In Salom SM, Tigner

477 TC, Reardon RC (Eds.) Proceedings of the 1st Hemlock Woolly Adelgid Review; 1995 October

478 12; Charlottesville, VA. USDA Forest Service, Forest Health Technology Enterprise Team 96-

479 10. Morgantown, WV: 89-101.

480 Murdoch WW (1966) “Community structure, population control, and competition” - a critique.

481 Am Nat 100: 219-226. https://doi.org/10.1086/282415

482 Oksanen L, Fretwell SD, Arruda J, Niemela P (1981) Exploitation ecosystems in gradients of

483 primary productivity. Am Nat 118:240-261. https://doi.org/10.1086/283817

484 Oten KLF (2011) Host-plant selection by the hemlock woolly adelgid, Adelges tsugae Annand:

485 sensory systems and feeding behavior in relation to physical and chemical host-plant

486 characteristics. PhD dissertation, Department of Entomology, North Carolina State University,

487 Raleigh, North Carolina, USA. 
488 Power ME (1992) Top-down and bottom-up forces in food webs: do plants have primacy. Ecol 489 73:733-746. https://doi.org/10.2307/1940153

490 Preisser EL, Lodge AG, Orwig DA, Elkinton JS (2008) Range expansion and population 491 dynamics of co-occurring invasive herbivores. Biol Invas 10:201-213.

492 https://doi.org/10.1007/s10530-007-9123-z

493 R Core Team (2021) R: a language and environment for statistical computing computer 494 program. R Foundation for Statistical Computing, Vienna, Austria. https://www.R-project.org/

495 Strong DR, Lawton JH, Southwood SR (1984) Insects on Plants. Community Patterns and 496 Mechanisms. Harvard University Press, Cambridge, Massachusetts, USA.

497 Sussky EM, Elkinton JS (2014) Density-dependent survival and fecundity of hemlock woolly 498 adelgid (Hemiptera: Adelgidae). Environ Entomol 43:1157-67. https://doi.org/10.1603/EN13356

499 Sussky EM, Elkinton JS (2015) Survival and near extinction of hemlock woolly adelgid 500 (Hemiptera: Adelgidae) during summer aestivation in a hemlock plantation. Environ Entomol 501 44:153-159. https://doi.org/10.1093/ee/nvu007

502 Vidal MC, Murphy SM (2018) Bottom-up vs. top-down effects on terrestrial insect herbivores: 503 A meta-analysis. Ecol Lett 21:138-150. https://doi.org/10.1111/ele.12874

504 Wallace MS, Hain FP (2000) Field surveys and evaluation of native and established predators 505 of the hemlock woolly adelgid (Homoptera: Adelgidae) in the southeastern United States.

506 Environ Entomol 29:638-644. https://doi.org/10.1603/0046-225X-29.3.638 
507 Weed AS, Elkinton JS, Lany NK (2016) Density-dependent recruitment and diapause in the 508 spring-feeding generation of hemlock woolly adelgid (Hemiptera: Adelgidae) in western North 509 America. Environ Entomol 45:1352-1359. https://doi.org/10.1093/ee/nvw107

510 Weston PA, Harper RW (2009) Potential of Tsuga spp. from western North America and Asia 511 as replacements for eastern hemlock (Tsuga canadensis). Arboric Urban For 35:5-9.

512 Wickham H (2009) ggplot2: elegant graphics for data analysis. Springer, New York

513 Young RF, Shields KS, Berlyn GP (1995) Hemlock woolly adelgid (Homoptera: Adelgidae):

514 stylet bundle insertion and feeding sites. Ann Entomol Soc Am 88:827-835.

515 https://doi.org/10.1093/aesa/88.6.827

516 Zar JH (2010) Biostatistical Analysis. 2nd edn. Prentice-Hall/Pearson. Upper Saddle River, 517 New Jersey, USA.

518 Zilahi-Balogh G, Lamb A, Salom S, Kok L (2003) Seasonal abundance and synchrony 519 between Laricobius nigrinus (Coleoptera: Derodontidae) and its prey, the hemlock woolly 520 adelgid. Can Entomol 135:103-115. https://doi.org/10.4039/n02-059 


\section{$521 \quad$ Figure Captions}

522 Fig. 1 Mean $( \pm$ SE) density of Adelges tsugae life stages on bagged and unbagged branches Washington Park Arboretum in Seattle,

523 Washington on a) eastern hemlock 2015-2016, b) western hemlock 2015-2016, c) eastern hemlock 2017-2018, and d) western

524 hemlock 2018. Black bars: "Bag" treatment; Grey bars: "No Bag” treatment. Significant differences in density between treatments are

525 indicated in Fig 1 by * for $P<0.05$ and ** for $P<0.01$. Statistical significance refers to results from our GLMM models. Density

526 figures were split by experimental round (2015-2016 and 2017-2018) and tree species (eastern hemlock and western hemlock).

527

528 Fig. 2 Mean $( \pm \mathrm{SE})$ a) abundance of Adelges tsugae (HWA) (0-3; $0=$ No HWA ovisacs, 1 = 1-10 HWA ovisacs, $2=11-100$ HWA

529 ovisacs, and $3=101+$ HWA ovisacs) and b) percentage of branches infested with HWA in three geographic regions of Washington

530 (Seattle, Olympic Peninsula, and Cascades) and New England in summer of 2020. Different letters above bars indicate significant

531 differences at $\alpha<0.05$. 


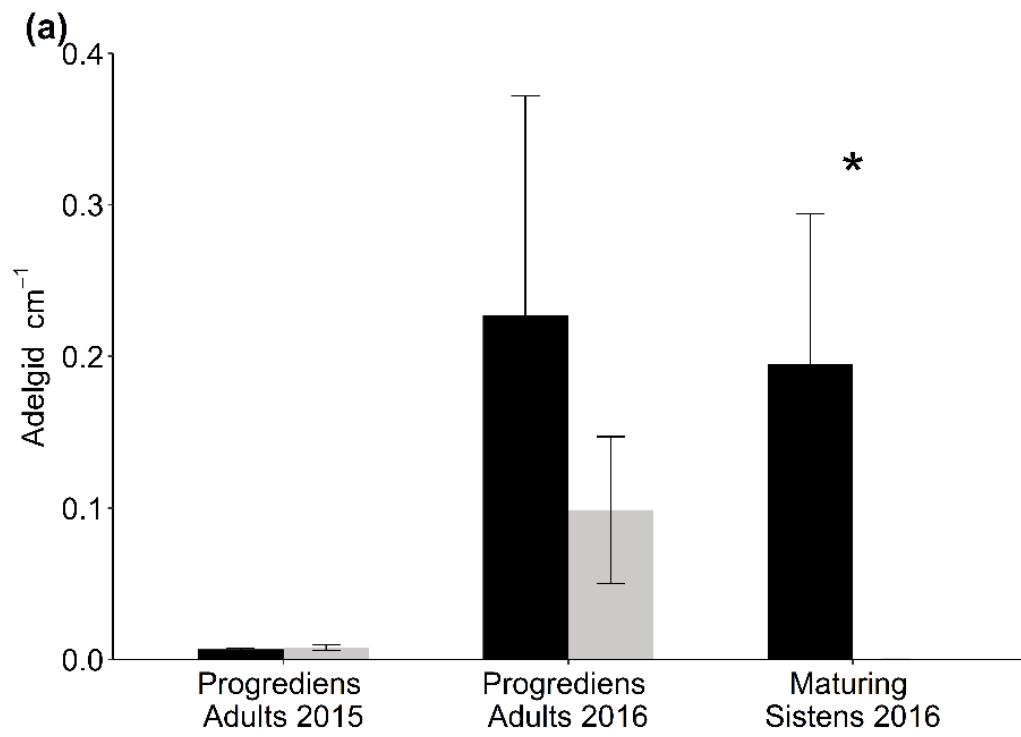

(b)

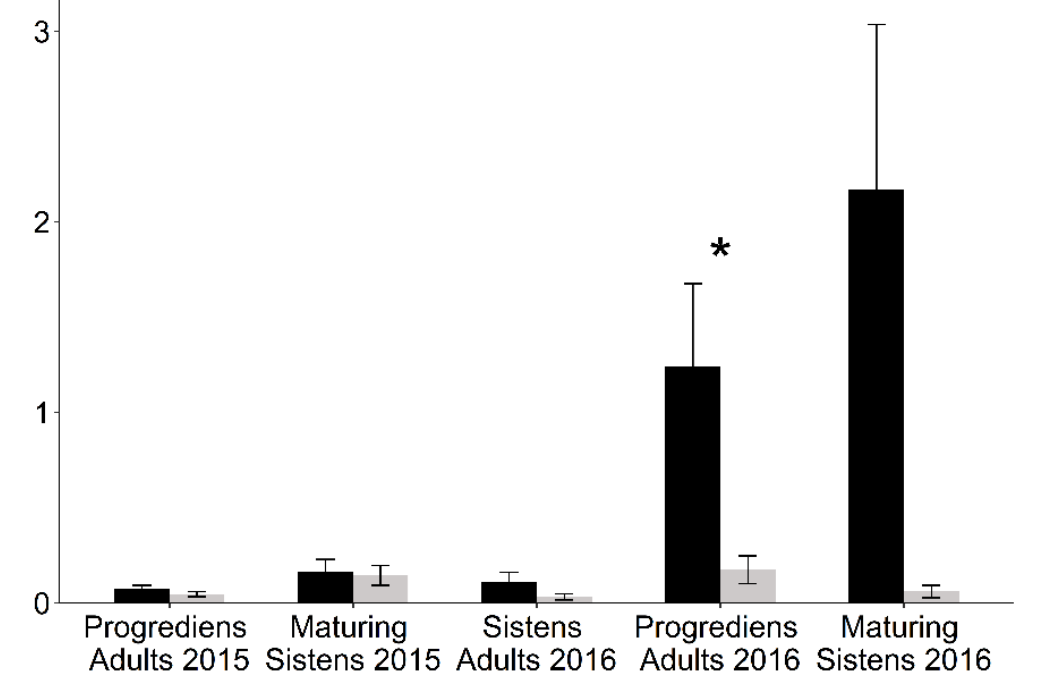

(c)

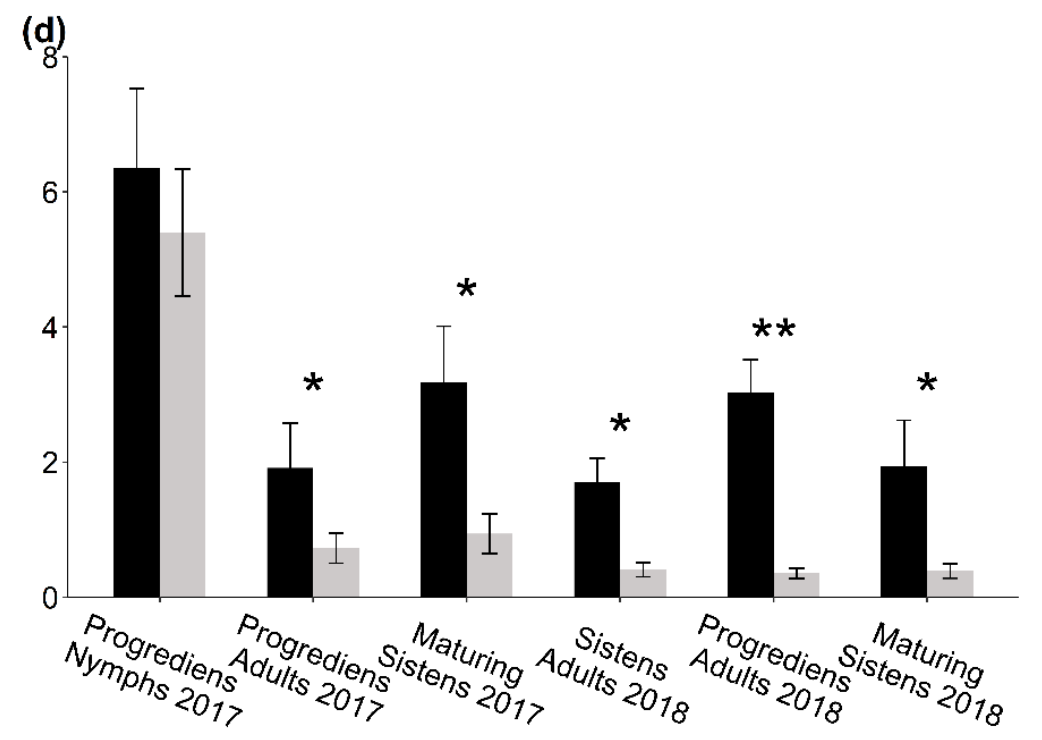

Figure 1. 

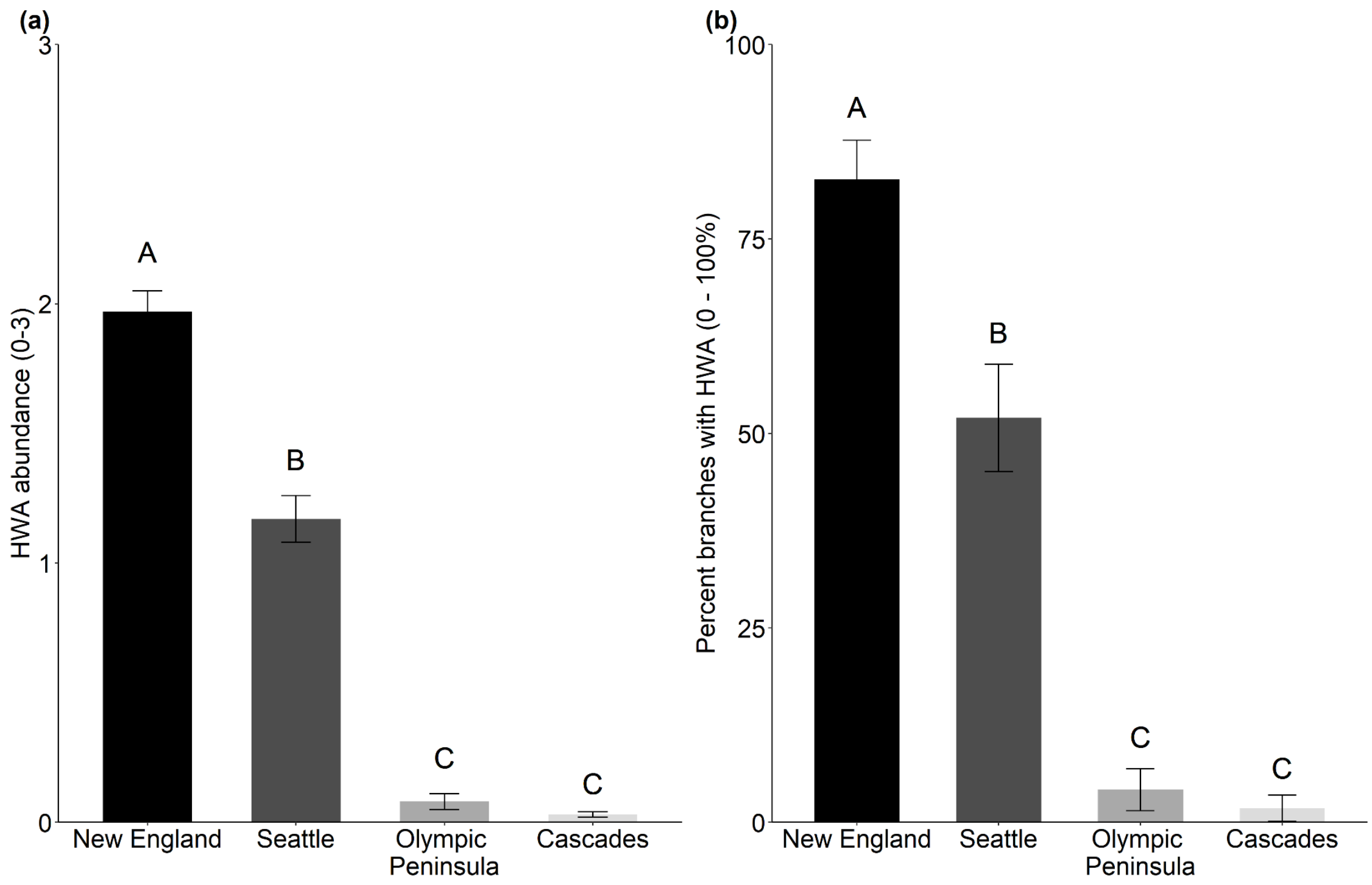

Figure 2. 
Table 1. Establishment of HWA by tree species in 2017-2018. Values listed are the number of branches with live HWA out of the total number of branches inoculated.

\begin{tabular}{|c|c|c|c|c|}
\hline \multirow[b]{2}{*}{ Generation } & \multicolumn{2}{|c|}{ No. Branches with HWA / Total Branches } & \multirow[b]{2}{*}{$\mathrm{z}$ value } & \multirow[b]{2}{*}{$\mathrm{P}$ value } \\
\hline & Eastern Hemlock & Western Hemlock & & \\
\hline All Generations Combined & 0.414 & 0.807 & 6.579 & $<0.001 * * *$ \\
\hline Progrediens Nymphs 2017 & 0.65 & 0.850 & 1.426 & 0.1540 \\
\hline Progrediens Adults 2017 & 0.650 & 0.850 & 1.426 & 0.1540 \\
\hline Sistens Nymphs 2017 & 0.400 & 0.850 & 2.762 & $0.0058 * *$ \\
\hline Maturing Sistens 2017 & 0.350 & 0.850 & 3.009 & $0.0026 * *$ \\
\hline Adult Sistens 2018 & 0.300 & 0.850 & 3.252 & $0.0012 * *$ \\
\hline Progrediens Adults 2018 & 0.250 & 0.800 & 3.265 & $0.0011 * *$ \\
\hline Maturing Sistens 2018 & 0.300 & 0.600 & 2.087 & $0.0369 *$ \\
\hline
\end{tabular}

Significant effects at $P<0.05$ are in bold. Significance symbols for $P<0.001(* * *),<0.01(* *),<0.05(*)$ 
Table 2. Mean $( \pm \mathrm{SE})$ percent survival, number of branch pairs, and results of the Generalized Mixed Model analyses comparing survival of Adelges tsugae by treatment for each generation (progrediens, sistens) and host tree species (western hemlock, eastern hemlock).

\begin{tabular}{|c|c|c|c|c|c|c|c|}
\hline & HWA Generation & Hemlock Species & Treatment & Survival (\%) & $\mathrm{n}$ (pairs) & $\mathrm{z}$ value & $P$ \\
\hline \multirow[t]{6}{*}{ A) } & $\begin{array}{l}\text { Progrediens Adults } \\
\text { June } 2017\end{array}$ & Western & Bag & $31.6 \pm 5.6$ & & & \\
\hline & & & & & 17 & -23.97 & $<0.001 * * *$ \\
\hline & & & No Bag & $12.2 \pm 4.6$ & & & \\
\hline & & Eastern & Bag & $25.1 \pm 5.2$ & & & \\
\hline & & & & & 13 & -4.17 & $<0.001 * * *$ \\
\hline & & & No Bag & $19.5 \pm 5.0$ & & & \\
\hline \multirow[t]{6}{*}{ B) } & $\begin{array}{l}\text { Maturing Sistens } \\
\text { November } 2017\end{array}$ & Western & Bag & $65.7 \pm 6.2$ & & & \\
\hline & & & & & 14 & -1.158 & 0.2467 \\
\hline & & & No Bag & $60.4 \pm 10.8$ & & & \\
\hline & & Eastern & Bag & $30.4 \pm 12.2$ & & & \\
\hline & & & & & 7 & -2.362 & $0.0182 *$ \\
\hline & & & No Bag & $23.9 \pm 10.9$ & & & \\
\hline
\end{tabular}

Significant effects at $P<0.05$ are in bold. Significance symbols for $P<0.001(* * *),<0.01(* *),<0.05(*)$ 
Table 3. Results from multiple studies testing host susceptibility of eastern hemlock (T. canadensis) and western hemlock ( $\mathrm{T}$.

heterophylla) to hemlock woolly adelgid by quantifying adelgid density, survival, fecundity, and proportion of host trees infested.

Significant effects $(P<0.05)$ shown as "<" and " >" while non-significant effects shown as "=". HWA lineages as described by Havill et al. 2016.

Experimental Location and HWA HWA density, survival, and fecundity on

Lineage

T. canadensis vs T. heterophylla

Study
A) Hampden, CT, USA
Japanese
T. canadensis $>$ T. heterophylla (survival and fecundity)
McClure 1992
Raleigh, NC, USA
Japanese
T. canadensis $>$ T. heterophylla (progrediens density)
$\mathrm{T}$. canadensis $=\mathrm{T}$. heterophylla (fecundity)
Jetton et al. 2008
C) Blairsville, GA, USA
$\mathrm{T}$. canadensis $=\mathrm{T}$. heterophylla (total adelgid per centimeter)
T. canadensis $=T$. heterophylla (fecundity)
Joseph et al. 2011
(Looking only at unfertilized tree results)
D) Crossnore, NC, USA
Japanese
T. canadensis $>$ T. heterophylla (36 times more likely to be infested)
Oten 2011 (Thesis
Chapter 7)
E) Katonah, NY, USA
T. canadensis $>$ T. heterophylla (percentage of trees infested)
Weston and Harper
Japanese
T. canadensis $<$ T. heterophylla (fecundity)
2009
F) Seattle, WA, USA
Western North American
Mausel 2005 


\section{Supplementary Files}

This is a list of supplementary files associated with this preprint. Click to download.

- CrandalletalData02.09.2022.xIsx

- CrandalletalSupplementaryMaterials02.09.2022.pdf 